\title{
Crisis and Hope among the World's Urban Poor: Religion responds to Covid-19
}

\author{
Grace R. Dyrness \\ The Hub for Urban Initiatives, California, USA \\ <gracdyrness@urban-initiatives.org>
}

\begin{abstract}
We are living in unprecedented times of migration flows. There are over 271.6 million international migrants globally, most of them women and children under the age of 19, most of whom move to cities causing fast growth in urban areas, particularly in the informal settlements and slums, places of poverty, densely populated with inadequate household water and sanitation, little or no waste management, overcrowded public transport and limited access to formal health care facilities. As they seek to establish themselves in the city, many migrants turn to religion for support. Faith communities become places where they can find 1) a source of community; 2) where resources are available to meet their needs; 3) for support in times of trouble; and 4) where praying becomes a resource for survival. As the Covid-19 pandemic began spreading throughout the world and cities were locked down, people were requested to stay in their homes, but yet they had no income or food, causing hunger, anxiety, fear and violence. But once again faith communities, already on the ground, have responded, and from these responses are lessons to be learned on how to support bottom-up approaches that build resiliency and strengthen informal communities in times of crisis. 5 principal ways that religious communities are helping to build resilient cities: data collection, developing partnerships and networks, providing information and communication, inclusive and diverse engagement, and spiritual comfort and guidance. These types of responses create resilient communities than can withstand future pandemics.
\end{abstract}

Keywords: informal settlements, Covid-19, faith responses

\section{Introduction}

The remarkable growth of cities in recent decades has intensified a number of humanity's most pressing challenges. It has also presented many of our greatest opportunities to protect people, prosperity and planet. Covid-19 has laid bareand indeed heightened - both these challenges and these opportunities. [1] 
We are living in unprecedented times of migration flows. The International Organization of Migration (IOM) reports that as of mid-2019 there are 271.6 million international migrants globally, up from 153 million in 1990. Almost $48 \%$ of them are women and $14 \%$ are children under the age of 19.[2] Most of these migrants move to cities causing fast growth in urban areas. It is expected that the world's urban population will be at $70 \%$ by 2050 with close to $90 \%$ of this to be in Asia and Africa.[3] However, long before this recent flow of immigrants to cities, religious and faith-based organizations have been on the ground, already serving vulnerable communities. As immigrants moved into cities such as Los Angeles, these religious communities began serving them also. In a similar fashion, faith communities on the ground in urban informal settlements and slums reach out in myriad ways to respond to the issues their people face on a daily basis, and even more so during pandemics such as the Covid-19 virus. In this paper I attempt to look at some of the challenges and opportunities faced by these communities through the lens of religion, faith, and spirituality. I explore ways in which religion and faith support the immigrant communities in Los Angeles in order to highlight similar ways in which they are now responding to the Coronavirus pandemic in the informal urban settlements and slums of the Global South. The people living in these areas live from crisis to crisis, such as the HIV/AIDs pandemic and the Ebola virus, learning lessons that are now being carried forward during Covid-19 pandemic. From Los Angeles to the Global South, religious institutions and faith organizations provide pathways of hope and resiliency, teaching us lessons that pave the way forward into a better, flourishing and sustainable future. They are vital partners for government and large non-governmental organizations, especially in times of crisis. By listening to them, gaining from their experience, and working with them, our cities can better withstand any future pandemics.

\section{Immigrants and Religion}

In the city and county where I live, almost $35 \%$ of the population is foreign born. A vast majority are Hispanic or Hispanic heritage. Los Angeles is said to be the largest Korean city outside of Korea, [4] we have thousands of Iranians so much so that a section of the city is called Irangeles. And there's Little Saigon, and Historic Filipino Town. We have at least 20,000 Cambodians. Global cities such as Los Angeles are places of destination to those leaving their countries for economics, war, climate, and sometimes adventure. Their hopes and dreams are for a better, safer, life for themselves and for their families. 
In her book, The Global City, Saskia Sassen [5] states that global cities are held up by a host of lowwage, primarily immigrant labor. What is evident from her analysis and that of other scholars is that migration flows have increasingly built up our cities, creating centers where a large percentage of the population is foreign born, as well as migrants who have moved from rural areas of the country. [6] Immigration provides a nearly inexhaustible supply of cheap, flexible labor that is crucial for capital accumulation centered in world cities, and it also produces the multicultural milieu that is distinctive to world cities.

Sanderson and his colleagues completed a statistical analysis that substantiates what Sassen and others had been saying. The results of their analysis clearly demonstrate that "world cities are not only key sites for corporate control of the world economy and for business and tourist flows, but they are also central in global flows of immigrant labor."[7] While the main destinations of immigration have been cities in the Northern hemisphere, since the 1990s, migration within Asia, for example, has grown, particularly from less-developed countries with massive labor surpluses to fast-growing newly industrializing countries.

India is experiencing large-scale internal migration and urbanization. In 2009 "there were an estimated 100 million migrant workers, many of them poor rural-urban migrants who return temporarily to their villages when agricultural labor demands are high and, permanently in old age. In China, massive flows from rural areas in the center and west to the new industrial areas of the east (especially Beijing, Shanghai, and the Pearl River Delta) have created a 'floating population' of 100 to 150 million people. Forced internal displacement is also a major issue. In 2006, there were 3 million internally displaced persons (IDPs) in Asia, not including the 2.7 million in the Middle East. The main causes for such displacement were conflict, violence, or human rights abuses. Millions more are displaced by development projects, such as large dams, while others flee environmental change and natural disasters like volcanoes and floods."[8]

How do these millions of migrants adjust to the complex, often unorganized and unplanned urban context in which they find themselves? I will focus on work in Los Angeles that I did as part of research teams with other faculty at the University of Southern California, primarily through the Center for Religion and Civic Culture. I believe that our findings shed some light on the lives of immigrants that have parallels in other parts of the world. The way religious institutions and faith communities have reached out to serve newly arrived immigrants in our city, demonstrate the vital role that these play in making our cities resilient 
and helping them thrive. Thus in times of crisis such as the Covid-19 pandemic, these communities of faith become essential to helping people learn to cope and provide hope for a better future.

\section{Religious Practice in Cities}

Not only do cities provide a variety of opportunities for employment, entertainment, living styles, culinary diversity, educational opportunities and much more, they also provide many options for religious engagement, a diversity of paths to spiritual and mystical presence. In our research we have found four major ways in which faith and its practice have been particularly relevant to the women I have worked with: 1) religion as a source for building and strengthening a sense of community; 2) a source for supplying a variety of needs, from providing emergency food and clothing, to helping to find employment, to building the skills needed to flourish; 3 ) support in time of trouble; and 4) using prayer as a resource for survival.[9] I will briefly discuss these as examples of ways in which religion provides a resource for flourishing and resiliency in the midst of the urban challenges people encounter.

\section{A source of community}

Religion addresses the problem of loneliness by providing entry to a familiar community with familiar beliefs and practices that give structure and meaning to life - all elements of stability that are especially important in a new environment where expectations about what to believe or think are unclear. The temple is a place for community with fellow immigrants and with those who come from the same traditions. It is a place where one can speak one's native tongue, eat native food, and not insignificantly, find a husband (or wife) who shares the same cultural background [10]. The Wat Thai Temple in North Hollywood, for example, has established a Thai Cultural Center right next to the Temple so that the traditions from the homeland are not lost on the next generation. Cambodian women send their young sons to the Khemara Budhikarm in Long Beach to be mentored by the priests in hopes that they will get engaged in Cambodian culture and resist joining the gangs in Los Angeles. Religious institutions, therefore, welcome the stranger, provide a community that helps replace the one left behind, and enable new generations to connect with the past of their parents.

\section{Supplying all needs}

Migrants also often rely on religious institutions for provision of daily needs. These needs vary across the spectrum but most often are related to the needs for their children, whether it be food, health, or, especially, education. Commonly this is accomplished through the establishment of thrift stores and food pantries, making job connections, engaging in job training, and sometimes even providing 
basic health care. So a Mosque in Philadelphia offers halal grab-and-go lunches and delivers fresh produce to families in need in its community.[11]

For migrant women the ability to turn to their religious place of worship for supplying their needs is a great source of comfort and strength, and even survival. Whatever their needs, they know that ultimately they can count on their faith and their religious community to help them get through the rough times, particularly in the early years of adaptation to their new city.

\section{Support in time of trouble}

Religious leaders often blur the line between counselors and spiritual mentors, even when they refer their flock to specialists when they are not capable of providing all the help needed. During our study of religion and immigrants in Los Angeles in 2000, we visited the Cambodian Temple Khemara Bhuddhikarm referred to above. Several hundred people were gathered to pay homage to their departed relatives. As Rev. Kong Chhean burned slips of paper with the deceased ones' names, family units sat together on the floor sharing a meal and remembering the events that brought them to this strange city. There was a young woman in the group who, as a child, had walked through the "killing fields" over dead bodies as she and her family made their escape. This kind of trauma can often express itself in physical illnesses that are not always treatable by a medical health care practitioner but require specific mental health interventions. At the time there were 150 documented cases of psychosomatic blindness among women in Long Beach who witnessed the torture of their husbands, the rape of their daughters, and the destruction of their villages. The women feel safe talking about this to their priest. The Rev. Kong Chhean, who has training in psychology, refers his members to a local clinic for medication and treatment when they are amenable to western styles of intervention, and otherwise he performs magical incantations to help them cope with the trauma of their past.[12] It is in the Temple where the women find the help they need to support them in their troubles. The women at the Temple also turn to Rev. Chhean and his fellow priests to give guidance and support to their children, particularly the young men, to keep them out of trouble, out of gangs. This type of support is especially critical for them as they navigate a complex new life and seek to raise children in the midst of a culture they are only beginning to understand.

Prayer as a resource for survival

Personal prayers are at the core of many of the migrants' faith. Prayer often serves as a way to cope with the struggles that they face in the city. Whether it be praying for their kids who are engaged in violent gang activity or for safety and protection in the insecure 
slum and squatter settlements that many live in, prayer is a connection with the supernatural, the transcendent, that lifts them out of the ordinary and offers them hope of a God who can enter into their situation and provide the help they need. As parents leave their children behind in care of grandparents or other relatives, the deep sorrow of separation is a daily reminder of the world they have left behind, particularly when they are caring for the children of their employers. Thus both mothers and fathers pray to an omnipresent supernatural being to help with their personal suffering. Mothers ask God to watch over their children and keep them safe.

Prayer as a coping mechanism not only helps parents cope with their daily challenges as workers in the United States (and many other countries), but prayers to God help collapse the physical distance between them and their families back home. In sum, prayer is one way transnational mothers and fathers transcend distance from their families, and while the distance is still felt on some level, it helps them cope with the separation.[13]

\section{Religion and the Covid-19 Pandemic}

An immigrant to the city will therefore appeal not only to her family and friends in the city, but often to the religious institutions that she is familiar with and that she can count on as she adjusts. People in the city have developed a resiliency that is often based on the spiritual connections they have to these faith traditions. It helps them in their day to day living, and it helps them especially in times of crisis. And there is no bigger crisis globally right now than the Covid-19 virus.

The quote that is at the beginning of this paper is worth repeating:

The remarkable growth of cities in recent decades has intensified a number of humanity's most pressing challenges. It has also presented many of our greatest opportunities to protect people, prosperity and planet. Covid-19 has laid bare - and indeed heightened - both these challenges and these opportunities.[14]

Cities have been at the center of the spread of the Coronavirus. The density of the population lends itself to the spread of a virus that is airborne and is highly contagious and where social distancing is difficult. With the global death toll from the virus surpassing 1 million people,[15] hospitals are overwhelmed, health care workers have been seriously impacted by illness and often death, and lockdowns have caused huge economic losses for people, particularly for those living in the slums and informal settlements of the Global South. Already densely populated with inadequate household water and sanitation, little or no waste management, overcrowded public transport and limited access to formal health care facilities, informal settlements are especially vulnerable 
to a pandemic such as Covid-19.

Compounding the physical nature of their habitat, slum residents mostly work in the informal sector of the economy with unstable incomes and no or minimal savings. And the loss of income from lockdowns and stayat-home orders threatens the ability of residents to pay rent, find adequate health care, and clearly unable to keep practices of social distancing so vital to stopping the spread of disease.

The pandemic has also presented us with an urban paradox. On the one hand cities have been absorbing migrants by the thousands. Now suddenly many of these migrants, people who have been working as day laborers, or in the formal and informal economy, are de-urbanizing rapidly and relocating to their villages and family homes, putting pressure on limited land resources and increasing the potential for conflict.[16] Images of these migrants have been in our newspapers and social media. And of course, one wonders when and if they will ever return to the cities and how will the cities cope with the loss of laborers who hold up our way of life.

UN Habitat[17] challenges the world to emerge stronger from this crisis and move closer to achieving the Sustainable Development Goals by enabling inclusive, safe, resilient and sustainable cities and communities to thrive and prosper. The challenge is getting from here to there. The loss of income from lockdowns and stayat-home orders threatens the ability of residents to pay rent, find adequate health care, and clearly unable to keep practices of social distancing so vital to stopping the spread of disease. The impact of government policies is disproportionately affecting the poor, making the inequities in our cities even more glaring.

In the midst of this global crisis, another story has been emerging. Just as faith communities have risen to the challenge of caring for immigrants in cities, similarly in numerous ways they are now rising to the challenge of caring for the most vulnerable affected by the: providing food and other basic necessities; distributing soap and hand sanitizers; setting up water stations; providing phones and "loads" to build digital capacity; comforting those who are mourning; distributing masks; teaching basic health and hygiene for this pandemic, and in so many other ways going outside the boundaries of the church, the mosque, the temple, to care for one another. As Miller[18] says "Out of the crisis there is evolving the seeds of an ethic of care and awareness of the deeper structural issues that affect our collective well-being. The better angels of our common humanity are finding voice."

\section{Lessons from below}

Lessons are emerging that will make our communities more resilient and prepare us for any future pandemic. 
These communities are teaching urban areas how to be resilient and show us that rather than being objects of our concern, they actually are the resources we need to help us create conditions where vulnerable residents of our cities can become thriving and productive in their own ways. Civil society, particularly communities of faith, rise to the occasion to serve their neighborhoods, as has been pointed out above, when migrants arrive and need support adjusting to the city. In the same way, my research has uncovered many ways that they are similarly responding to the crisis of the Covid19 pandemic. The global media has been quick to point out the gravity of the pandemic but has often missed this other story. Shane Preuss[19] points out that in Indonesia the Australian media has painted a picture of a country that is hapless and helpless in the midst of this pandemic's tragic effects. Yet, Preuss says, Indonesians have overcome many great ordeals before and evidence suggests that "Indonesians have learned to band together when times are tough, both feeling a responsibility and taking great joy in helping each other when needed," including raising funds to support informal sector workers, such as street food sellers, scavengers, and motorcycle taxi drivers. Medical students from 158 universities also signed up to volunteer. These are the types of responses coming from faith based communities as well, and from these responses are lessons to be learned on how to support bottom-up approaches that build resiliency and strengthen informal communities in times of crisis. Governments and large global non-governmental organizations need to recognize the important role the faith-based organizations and institutions play and learn to support and partner with them. I suggest 5 principal ways that religious communities are helping to build resilient cities.

Know your community: The importance of accurate data.

One of the biggest challenges in responding to a pandemic like Covid19 is the lack of data. 'Slums' are hard to know. The informal or illegal status of many deprived settlements often undermines both the collection of data and the implementation of policies to improve health. Data is not usually disaggregated by slum and non-slum, or it is simply not collected, especially for health.[20] How do you develop preparedness and response plans if you do not even know the number of people living in an area? Such was the case when the Institute for Studies in Asian Church and Culture (ISACC) in Manila began developing a plan to provide food and other resources to surrounding squatter settlements. Who needed the most help? The local government office had a list of people but it was inaccurate, once the ISACC staff attempted to deliver food and supplies. 
The lack of data made it imperative that they first had to go door to door to gather the information they needed: how many people were living in the house, who were those most deeply affected with loss of income, and so forth. Now with the new database, they could easily identify who needed the help the most. [21]

Finding the community based organizations that are already gaining expertise in data collection and joining them is an important first step in responding to a crisis or disaster. In Costa Rica, Casa Adobe, a Christian community in Heredia, has set up a google document with all the information about the surrounding neighbors in order to know who is most vulnerable in a crisis and thus be able to reach out immediately in response to a disaster. Churches, mosques, and temples can build up extensive data on their surrounding communities that will give a clear picture of where the greatest needs are and give leadership to organizing their members to support the community.

\section{Develop partnerships and networks.}

Working in isolation does not build the cohesion for the kind of resiliency that is needed in times like this. In fact, Nakagawa and Shaw[22] found that the social capital found already in Japanese communities helped them deal with disasters such as earthquakes and tsunamis. Rather than solutions that are technological and top down, their findings resulted in a recommendation that people and communities need to be incorporated into the process of pre-disaster mitigation and/or postdisaster recovery initiatives]. In a study conducted by Yale University on arresting the spread of Covid-19 and improving the well-being of urban informal settlements, Corburn and his team found that most top-down strategies to arrest an infectious disease will likely ignore the often-robust social groups and knowledge that already exist and they recommend that every slum and informal settlement institute emergency planning committees to build resiliency and rapid response in the face of pandemics such as Covid-19. [23]

The kind of social cohesion and social capital necessary for resiliency in the midst of crisis is often built by communities of faith. While not always bridging across faith traditions, very often they have been developing such partnerships along the way in order to respond to community issues. One example is the Alliance Development Trust (ADT) in Sri Lanka.

As the Covid-19 virus began to spread throughout the country of Sri Lanka, the Department of Health saw the need to move quickly and educate the people on ways to guard their health against this pandemic. The Department called upon the ADT to assist them in this task, well aware of the island-wide network of churches 
that were a part of the Alliance. ADT offered support through the churches, but also called upon interfaith leaders who were organized under the Inter Religious Peace Foundation. The Foundation had originally been set up in 1993 by religious clerics who were Hindu, Muslim, and Buddhists, trying to bring about peace between the different religious and ethnic communities that were polarized along religious and ethnic lines during the conflict in Sri Lanka. The ADT invited these leaders to join them in this new campaign to fight a common enemy, which at that time was leprosy. Not only was the project highly successful, but it succeeded in developing a trust relationship between the minority Christian pastors and Hindu, Muslim and Buddhist priests and leaders. With these relationships already in place in time of Covid-19 it was natural for the Government and the World Health Organization (WHO) to turn to the ADT and other community partners for assistance in mitigating against the ravages of the pandemic. This network set to work to inform their members and their neighbors about the realities of the virus and what they should do to protect themselves and their families. The leader of the Alliance Development Trust acknowledges that building those interfaith relationships requires time and should be worked on prior to any crisis so that the social infrastructure is already in place. And he added, "We are stronger together."[24] Working with faith communities becomes central to accomplishing the task of mitigating the impact of a pandemic such as Covid-19.

Partnerships must be developed with government offices such as the Ministry of Public Health and with agencies such as the World Health Organization. Their lack of knowledge and understanding of the real lives of the urban poor provides an opportunity for the faith-based and community organizations to be the link they need and amplify the important messages they need to hear. But faith communities need to build trust by demonstrating that they are all part of the same community and must work together to withstand these crises. The hard work of establishing those relationships that build social cohesion must be done long before any crisis develops. In an example from Kolkata, India, the Sikh community was approached by the nodal officer of the Kolkata Municipal Corporation who had created temporary quarantines and shelters for rag pickers, beggars, and women and children living on the street. The municipality was seeking help to feed these people and partnered with the Sikh community, along with the Indian Humanity Assistance Foundation, and the Kolkata Response group. Together the team has been cooking 3,500 meals a day. It has also created four mobile units which distribute dry rations, 
medicines, and more to other poor people in the city.[25] By working together they have been able to expand outreach way beyond the capacity of any one member of the team.

Sometimes faith communities reach across national borders to create those relationships, learn from each other, and build resiliency. Such is the case of the Informal Settlements and Cities Consortium (ISCC), a coalition of organizations working in informal settlements in Africa and Asia. As their communities began battling Covid-19 induced disruption and unprecedented spikes in a range of areas such as low food security, poor mental health, domestic violence, child abuse and job loss, a group of faith leaders working in these settlements acknowledged that the pandemic has shed light on a world where issues of inequality are stark. They feel the need to address the systemic and structural dysfunction that has led to inequality by developing new models of community development and tailor responses for informal settlements that do not rely on the broken (and now disrupted) systems. They believe there is an opportunity opening up to strengthen the assets within communities and use them as a springboard to flatten the Covid-19 curve, but given the complexity of the urban informal settlements, these faith leaders have reached across borders for support, resources, encouragement, and strategy development. Called together by the Center for Building Better Communities based in Melbourne, Australia, this group has leaders from Australia, Burundi, Cameroon, Kenya, Philippines, South Africa and Zambia. Bi-weekly zoom calls have been the way they are learning from each other and sharing their stories as they seek to plan for a future beyond Covid19. Implementation is happening at a local level and then results and impact are shared on the zoom calls. This is exactly the type of social capital that Nakagawa and Shaw[26] saw locally within communities in Japan but by expanding it across borders, the ISCC is multiplying the resiliency and creating a model for surviving and flourishing beyond Covid-19.[27]

\section{Information and communication is vital}

Developing good communication tools and methods is one way to ensure that people receive the right kind of knowledge to fight against the virus. Key to this is having access to information or communications technology. Life in Abundance, a Christian NGO in Africa, has developed a whole series of infographics that are disseminated through their networks in the informal settlements, as well as on posters, T-shirts and banners. They distributed solar powered tablets for children and use cell phone messaging to provide up-to-date information.[28] In Cambodia, Alongsiders International, took advantage of the many young people in their networks and asked them 
to create a video on Corona Virus for Kids. The youth collected information from doctors and other health workers and this video on YouTube is now being used widely and has been translated into Hindi, Tamil, and Nepalese.[29]

Governments have also become "enlightened" and understand the important role that faith communities can play in disseminating messaging on how to prevent the spread of the Coronavirus. For example, in Somalia, the government acknowledged that for public information campaigns about Covid-19 in Somalia to work, they should be designed within the "dominant framing" of religion, according to a new survey. About 38 percent of respondents viewed the pandemic through a religious lens. The responses to an open-ended survey by the Africa's Voices Foundation (AVF) included calls to respect the advice of the government, requests for more information, and claims about unproven remedies. Second to faith-based views of Covid-19 (for example calling for trust in God and prayer) was support for medically-advised practices and governmental advice. Overall, about one in 10 submissions included some kind of rumour, stigma (including blame on outsiders and non-believers), or misinformation. "Especially in Ramadan, people are turning to faith first, so any messaging needs to be with and through the sources they trust," reported Sharath Srinivasan of AVF. This is about understanding the experience of the virus from a community perspective, then delivering trusted and effective messaging to support healthy behaviours as well as communicating feedback to public health actors and authorities.[30]

In order to avoid large gatherings, Buddhist families in Sri Lanka were advised to stay home in May to celebrate Vesak, the festival that commemorates the birth, enlightenment, and death of the Buddha. Instead, they joined online services and connected digitally with their temple while making traditional lanterns in their homes using sustainable materials. Sri Lankan Christians were also reported to have decorated their churches and homes with Buddhist lanterns and flags in a show of interfaith solidarity.[31]

\section{Inclusivity and diversity.}

For communities to be resilient and to be able to withstand crises such as the coronavirus epidemic, outreach must be inclusive. Too often, as plans and strategies are being developed many critically important members are left out of these sessions. People with disabilities, women and girls, religious and ethnic minorities are often not included in conversations around strategies for the future of their communities. They have been seen only as beneficiaries of programs and not as critical players. Women, for example, bear the biggest burden of caring for the family and have the 
most knowledge for what their families and communities need and need to be central players in community planning yet they are not at the planning tables. Furthermore, lockdowns are fostering tension and strain leading to a rise in domestic abuse, rape, and girl pregnancies, in what the United Nations is calling "The Shadow Pandemic".[32]

Natalia Kanem. executive director of the UN World Population Fund is extremely concerned about the impact of Covid-19 on women and girls. "In a word, it is devastating. There are many women in situations of desperation right now and all this tallies up to devastating health and social consequences for that woman, for that girl, for that family, for that community", she said. "We were doing okay, we still needed to accelerate progress, but now here you have a situation where we could actually go backward. It's unacceptable." There is also growing anxiety about the increase in gender-based violence, with international and national organisations warning of a dramatic surge in cases of violence against girls and women. In Colombia, for example, reports of gender-based violence during lockdown increased by $175 \%$ compared with the same period last year, according to Plan International. "Genderbased violence has distinguished the pandemic [from other crises] because of the lack of movement and people being trapped in abusive situations", Kanem said. "The hotlines, the shelters, the counselling that is required has been increasing dramatically. It has happened in developed and developing countries.'[33]

The United Nations Department of Economic and Social Affairs[34] warns that "experience and evidence from previous outbreaks (including the Ebola epidemics in the Democratic Republic of the Congo, Guinea and Sierra Leone and the Zika virus disease) and other humanitarian emergencies indicate that sexual and reproductive health services, including pregnancy care, contraceptive services, sexual assault services and safe abortion, are likely to be scaled back. This can result in an increased risk of maternal mortality, unintended pregnancies and other adverse sexual and reproductive health outcomes among women and girls." From this experience, faith based organizations such as Life in Abundance in East Africa have redoubled their efforts to keep open and fully supplied any clinics they are running, focusing heavily on caring for women and girls, but also providing support for men who feel threatened by their inability to go out during lockdowns and provide financially for the family. This has been a part of LIA's strategy to reduce domestic violence and child abuse during this period of the pandemic.[35] Faith communities have been through multiple disasters and pandemics before; thus they provide essential resources to face this new challenge. 
The Wasun Gishu Children's Network in Eldoret, Kenya, is reaching out by establishing special services for women and for youth, setting up hygiene stations and distributing feminine supplies to girls.[36] Others are setting up hotlines and developing messaging on parenting tips and domestic violence. This is a key strategy of the Alliance Development Trust in Sri Lanka who has been disseminating these messages through radio and WhatsApp cell phone applications.

\section{Spiritual comfort and guidance}

Finally, in the midst of this pandemic, a sense of loneliness, fear, and isolation is causing many people to turn to religion for comfort. Just as the immigrants we referred to above turn to religion when they arrive in their new country, people are yearning for some meaning to the chaos that is surrounding them and often turn to their spiritual leaders, especially when fear and anxiety dominate their lives. Faith based organizations are reaching out by phone, by WhatsApp, through radio messages, to let people know where they can find comfort and help, particularly when loved ones get sick and/or die.

In Manila, Philippines, the Catholic Diocese of Kalookan, for example, found that people in the community had a high anxiety level, with an increase in suicides as lockdowns and lack of income generated hopelessness. As a response it created a Covid Hopeline, a hotline where people can call in and receive mental health emphasis, counseling with expert counselors, psychiatrists, and priests and nuns available for callers. In addition, it has organized psycho-spiritual seminars to help people understand what is happening at a deeper level than just the material losses.[37]

The Trauma Healing Institute in Philadelphia, U.S.A., has developed a manual with a series of lessons to support people during these times of Covid-19, which uses a "unique" method that unites proven mental health practices and engagement with God through the Bible.[38] The networks established by temples, mosques, and churches to distribute information and food to grass roots communities also serve as sources of encouragement and emotional support for their leaders. Many churches, such as mine, set up groups of parishioners who have been going through the rosters, calling people, writing to health care practitioners, and sending text messages of support.

However, it is not only the leaders of organized religious institutions or faith communities that are providing spiritual support at this time, but as Racelis found in Manila, lay people, often women, have an innate spirituality and helping response which leads them to share donations; to check on their neighbors, especially those under house 
confinement; planting vegetables in urban gardens and sharing the produce; holding prayer groups while socially distancing; and using the technological tools and messages that are provided to make sure all neighbors receive the information.[39] This strength is at the core of the faith responses we have described above.

\section{Conclusion}

In the same way that faith communities in cities have reached out and provided support, resources, counselling, and hospitality to newly arrived immigrants, they have also responded to the chaos caused by the Covid-19 pandemic. The lessons they have learned and the practices they have engaged in for years in cities are now proving resources for facing the current pandemic.

By developing data bases of their local communities, they have been able to be strategic in their outreach and build a base for future response. They have also been adept at developing partnerships and networks that have expanded the outreach of governments and large multi-national organizations. They have been innovative and creative, developing tools and disseminating information through a variety of technological means, using radio, cell phones, and social media to carry out messages on hygiene, parenting tips, resource availability, counselling, and other important information geared at adults, youth and children alike. Faith communities are also learning to be inclusive and diverse in their leadership structures and in the incorporation of people who are traditionally marginalized and left out of the decision-making process. By creating spaces that are disability friendly, making sure messaging is appropriately directed, providing resources and materials that are needed by girls and women, and in multiple other ways ensuring that partnerships include women, youth, and other excluded groups, faith communities are building the social cohesion necessary for a resilient community. Finally, and vitally, faith communities provide the spiritual care and support that people need in times of trauma and loss. Spiritual leaders have used online zoom rooms, cell phones, and other tools to be present and accompany their members and others in the community as they cope with the effects of the Coronavirus.

The relationships that are being built during this time must be nurtured so that they will continue to flourish long after this pandemic is over. Faith communities are on the ground providing food, masks, hygiene supplies and many other necessities as a way of accompanying people and demonstrating that all are together in this crisis, and in the midst of it, there is hope that together they will get through it and even begin to chart a way forward 
that creates a more equitable, just, and sustainable city.[]

\section{References}

[1] United Nations Policy Brief: COVID-19 in an Urban World, (7/2020).

[2] InternationalOrganizationofMigration, MigrationDataPortal, https://migrationdataportal. org/?i=stock_abs_\&t=2019, last accessed 2020/10/15.

[3] United Nations, Department of Economic and Social Affairs, https://www.un.org/ development/desa/en/news/population/2018-revision-of-world-urbanization-prospects. html, last accessed 2020/10/15.

[4] Brightwell, E. Pan Asian Metropolis, https://ericbrightwell.com/2020/06/02/pan-asianmetropolis-korean-los-angeles/, last accessed 2020/10/15.

[5] Sassen, S. The Global City: New York, London, and Tokyo. Princeton University Press, Princeton, New Jersey (1991)

[6] Sanderson, M., Derudder, B., Timberlake, M., Witlox, F. Are world cities also world immigrant cities? An international, cross-city analysis of global centrality and immigration. International Journal of Comparative Sociology 56 (3-4) 173-197, (2015).

[7] Sanderson, M., Derudder, B., Timberlake, M., Witlox, F. Are world cities also world immigrant cities? An international, cross-city analysis of global centrality and immigration. International Journal of Comparative Sociology 56 (3-4) 173-197, (2015).

[8] Castles, S., Miller, M. Migration in the Asia-Pacific Region. Migration Policy Institute, Washington D.C. (7/2009). https://www.migrationpolicy.org/article/migration-asiapacific-region, last accessed 1020/10/15.

[9] Dyrness, G.: Bearing Witness, Women in Cities as Agents of Transformation for God. In Meleis, A., Birch, E. (eds.). Women's Health and the World's Cities. University of Pennsylvania Press, Pennsylvania (2011).

[10] Miller, D., Miller, J., Dyrness, G. Religious Dimensions of the Immigrant Experience in Southern California. In Heikkila, E., Pizarro, R. (eds.). Southern California and the World. Praeger, Westport, CT, (2002).

[11] Griswold, E. An Imam Leads his Congregation Through the Pandemic. The New Yorker. $(5 / 8 / 2020)$.

[12] Miller, D., Miller, J., Dyrness, G. Religious Dimensions of the Immigrant Experience in Southern California. In Heikkila, E., Pizarro, R. (eds.). Southern California and the World. Praeger, Westport, CT, (2002).

[13] Dyrness, G.: Bearing Witness, Women in Cities as Agents of Transformation for God. In Meleis, A., Birch, E. (eds.). Women's Health and the World's Cities. University of Pennsylvania Press, Pennsylvania (2011).

[14] United Nations Policy Brief: COVID-19 in an Urban World, (7/2020).

[15] World Health Organization Coronavirus Disease (COVID -19) dashboard.

[16] Panfil, Y. Displacement, De-urbanization, and COVID 19, 8/3/2020. https:// www.newamerica.org/future-property-rights/reports/land-housing-and-covid-19/ displacement-de-urbanization-and-covid-19, last accessed 2020/08/31. 
[17] UN Habitat. Key Messages on COVID-19 and informal settlements. https://unhabitat. org/key-messages-on-covid-19-and-informal-settlements, last accessed 2020/08/30.

[18] Miller, D. Faith, Hope, and Creative Destruction: religious responses to COVID-19. Religion News Service. https://religionnews.com/2020/07/16/faith-hope-and-creativedestruction-religious-responses-to-covid-19/, last accessed 2020/07/16.

[19] Preuss, S. Indonesia and COVID-19, What the world is Missing. The Diplomat. $(2020 / 04 / 24)$

[20] Wilkinson, A. The Impact of COVID-19 in Informal Settlements: are we paying enough attention? University of Sussex, Institute of Development Studies, Brighton, UK. $(2020 / 03 / 10)$.

[21] Maggay, M. Institute for Studies in Asian Church and Culture, Manila, Philippines. Interview by the author, April (2020).

[22] Nakagawa, Y., Shaw, R. (2004). Social capital: A missing link to disaster recovery. International Journal of Mass Emergencies and Disasters, 22(1), 5-34 (2004).

[23] Corburn, J. et.al. Slum Health: Arresting COVID-19 \& Improving Well-Being in Urban Informal Settlements, Journal of Urban Health 2020 (in press) 5 April (2020).

[24] Gomez, P. Alliance Development Trust, Sri Lanka. Interview by the author, 26 April (2020).

[25] Ahluwalia, SS. Humanity over Hate: Religious Organizations Help with COVID-19 Relief. https://www.livemint.com/mint-lounge/business-of-life/humanity-over-hatereligious-organizations-help-out-with-covid-19-relief-11587041257785.html, last accessed 2020/04/16.

[26] Nakagawa, Y., Shaw, R. (2004). Social capital: A missing link to disaster recovery. International Journal of Mass Emergencies and Disasters, 22(1), 5-34 (2004).

[27] Smith, N., Van Eymeren, A. and Dyrness G. Responses to COVID-19: Sustainable pathways for informal settlements and vulnerable communities. Proposal by Centre for Building Better Community (https://www.community.how/) and the Hub for Urban Initiatives (https://www.urban-initiatiaves.org) (2020).

[28] Thamari, M. Glimpses of Hope and Regeneration in Nairobi City's Slums. Webinar on Crisis and Hope Among the World's Urban Poor: COVID-19 and the Church, Urban Shalom Society. http://urbanshalomsociety.org. 2020/06/16.

[29] Alongsiders International. https://www.facebook.com/Alongsiders/ videos/2 $17538946229059 /$ zzpfS TUwNzI3 MzI 1 OTpWSzoyMTg4OTg 0 MDYwNDA2MTQ/?comment_id=226110655319389\&reply_comment $\mathrm{id}=226653321931789 \&$ notif_id=1586988601465082\&notif_t=group_comment_ mention

[30] Srinivasan, S. https://www.thenewhumanitarian.org/news/2020/04/24/Africa-povertyflooding-coronavirus-religion-cheat-sheet) last accessed 2020/10/15.

[31] Lewis, C. Vesak goes digital as Buddhists head online to honor the Buddha. https:// www.buddhistdoor.net/news/vesak-goes-digital-as-buddhists-head-online-to-honor-thebuddha, last accessed 2020/10/15.

[32] Phumzile, M-N. Violence against women and girls: the shadow pandemic. https:/www. unwomen.org/en/news/stories/2020/4/statement-ed-phumzile-violence-against-womenduring-pandemic?gclid=EAIaIQobChMI6KH9nqyU7AIVEb7ACh30Qg2QEAAYASA AEgJWefD_BwE, last accessed 2020/10/20).

[33] Cousins, S. Covid-19 has 'devastating' effect on women and girls. www.thelancet.com Vol 396 2020/08/01. 
[34] World's Women. Coronavirus-19, Gender and Health. United Nations Department of Economic and Social Affairs Statistics (2020).

[35] Thamari, M. Glimpses of Hope and Regeneration in Nairobi City's Slums. Webinar on Crisis and Hope Among the World's Urban Poor: COVID-19 and the Church, Urban Shalom Society. http://urbanshalomsociety.org. 2020/06/16.

[36] Choge, E. Faith and Urban Resilience: A Collaborative Participatory Action Research in Hill School Kijiji, Eldoret Kenya. Paper presented at the Faith and Urban Resilience Workshop, Abu Dhabi, 2020/02/05.

[37] Racelis, M. Thinking of Cities as Spiritual Places. Paper presented at the Faith and Urban Resilience Workshop, Bali, Indonesia (virtual) 2020/10/02.

[38] Trauma Healing Institute. Philadelphia, PA. https://traumahealinginstitute.org/, last accessed 2020/10/26.

[39] Racelis, M. Thinking of Cities as Spiritual Places. Paper presented at the Faith and Urban Resilience Workshop, Bali, Indonesia (virtual) 2020/10/02. 